\title{
Produktivitas Tenaga Kerja Panen Kelapa Sawit dan Faktor-Faktor Yang Mempengaruhinya Pada Unit Usaha Batanghari di PTPN VI Jambi
}

\author{
Samuel Bindrianes* \\ Nida Kemala ** \\ Rizki Gemala Busyra** \\ *Alumnus Prodi Agribisnis Fakultas Pertanian, Universitas Batang Hari \\ **Dosen Prodi Agribisnis Fakultas Pertanian, Universitas Batang Hari
}

\begin{abstract}
Abstrak
Tujuan penelitian ini adalah untuk mengetahui Gambaran kegiatan usahatani kelapa sawit pada Unit Usaha Batanghari di PTPN VI Jambi, gambaran produktivitas tenaga kerja panen kelapa sawit, gambaran faktor (umur, lama pendidikan, masa kerja, jarak tempuh, jumlah tanggungan keluarga dan status tenaga kerja) yang mempengaruhi produktivitas tenaga kerja panen kelapa sawit, dan pengaruh faktor-faktor tersebut terhadap produktivitas tenaga kerja panen kelapa sawit. Jumlah tenaga kerja panen dalam penelitian ini sebanyak 31 responden, dengan metode pengumpulan data yang digunakan dengan metode survey. Untuk menguji pengaruh faktorfaktor yang mempengaruhi produktivitas tenaga kerja panen menggunakan metode regresi linier berganda. Kemudian dilakukan metode yang meliputi uji hipotesis, uji F, uji t, analisis koefisien determinasi $\left(\mathrm{R}^{2}\right)$ dan untuk menganalisa data menggunakan software SPSS versi 16.0. Dari hasil penelitian menunjukkan bahwa variabel independent (umur, lama pendidikan, masa kerja, jarak tempuh, jumlah tanggungan keluarga dan status tenaga kerja) secara simultan tidak berpengaruh terhadap produktivitas tenaga kerja panen dan secara partial variabel independent (status tenaga kerja) mempengaruhi produktivitas tenaga kerja panen sedangkan umur, lama pendidikan, masa kerja, jarak tempuh, jumlah tanggungan keluarga tidak mempngaruhi produktivitas tenaga kerja panen kelapa sawit.
\end{abstract}

\section{Kata Kunci: Produktifitas, Tenaga Kerja, Kelapa Sawit}

\begin{abstract}
This research was conducted at Batanghari Business Unit at PTPN VI Jambi which has the highest productivity compared to other business units. In this study, what will be examined is how to describe the activities of oil palm farming in Batanghari Business Unit in PTPN VI Jambi, how to describe the productivity of labor of palm oil harvest, how to describe factors (age, length of education, length of service, and labor status) affecting the productivity of the palm oil harvesting labor and whether there are any influence of these factors on labor productivity of oil palm crops.. Number of labor harvest in this research counted 31 respondents, with data collection method used by survey method. To test the influence of factors affecting labor productivity of harvest using multiple linear regression method. Then performed a method that includes hypothesis testing, $F$ test, $t$ test, determination coefficient analysis (R2) and to analyze data using SPSS software version 16.0. From the result of research indicate that independent variable (age, duration of education, work period, distance, number of dependent of family and labor status) simultaneously have no effect on labor productivity of harvest and partially independent variable (labor status) influence labor productivity harvest while the age, length of education, length of service, mileage, number of family dependents do not affect the productivity of the palm oil harvest workforce.
\end{abstract}

\section{Keyword: Produktivity, Employee, Palm Oil}




\section{PENDAHULUAN}

Pembangunan nasional suatu bangsa yang bertitik berat pada bidang ekonomi akan dapat berlangsung dalam jangka panjang dan makin lama makin maju jika dipenuhinya sejumlah syarat pokok, diantaranya dua syarat pokok yang penting, yaitu: (1) sumber daya manusia yang cukup banyak dan mempunyai kemampuan dan semangat kerja yang cukup besar, yang menggerakkan secara terpadu dan serasi semua kegiatan guna mengolah dan memanfaatkan sumber daya yang ada dalam proses pembangunan, (2) pasar yang cukup besar untuk menjual barang dan jasa yang dihasilkan dalam pembangunan (Soekartawi, 1987).

Dalam perekonomian Indonesia komoditas kelapa sawit memegang peranan yang cukup strategis karena hasil dari komoditas ini yang terus meningkat sehingga mempunyai prospek yang cerah sebagai sumber devisa. Kelapa sawit merupakan tanaman yang potensial, potensi ini terletak pada keragaman kegunaan minyak sawit. Minyak sawit disamping digunakan sebagai bahan mentah industri pangan, dapat pula digunakan sebagai bahan mentah industri non pangan.

Kelapa sawit yang merupakan komoditas perkebunan unggulan dan utama di Indonesia. Tanaman yang produk utamanya terdiri dari minyak sawit (CPO) dan minyak inti sawit (KPO) ini memiliki nilai ekonomis tinggi dan menjadi salah satu penyumbang devisa negara yang terbesar dibandingkan dengan komoditas perkebunan lainnya. Hingga saat ini kelapa sawit telah diusahakan dalam bentuk perkebunan dan pabrik pengolahan kelapa sawit hingga menjadi minyak dan produk turunannya. Dengan demikian, kelapa sawit memiliki arti penting bagi perekonomian di Indonesia (Fauzi, 2012).

Sebagai salah satu subsektor yang penting dalam sektor pertanian, subsektor perkebunan secara tradisional mempunyai kontribusi yang signifikan terhadap perekonomian Indonesia. Sektor ini mampu memberikan kontribusi penyediaan lapangan pekerjaan yang cukup signifikan. Bukan hanya itu, subsektor perkebunan juga merupakan salah satu subsektor yang mempunyai kontribusi penting dalam hal penciptaan nilai tambah yang tercermin dan kontribusinya terhadap Produk Domestik Bruto (PDB).

Perkebunan kelapa sawit di Jambi terdiri dari perkebunan rakyat, perkebunan swasta, dan perkebunan milik pemerintah. Salah satu perkebunan kelapa sawit milik pemerintah adalah PTPN VI yang membawahi 10 Unit Usaha. Dalam beberapa tahun terakhir Unit Usaha PTPN VI banyak mengalami perubahan seperti penambahan dan pengurangan luas areal yang mempengaruhi produksi dan produktivitas kelapa sawit. Untuk lebih jelasnya dapat dilihat pada Tabel 1. 
Tabel 1. Luas Areal, Produksi, dan Produktivitas Kelapa Sawit Unit Usaha PTPN VI

\begin{tabular}{|c|c|c|c|c|c|c|c|}
\hline \multirow[b]{2}{*}{$\begin{array}{l}\mathrm{N} \\
\mathrm{o}\end{array}$} & \multirow[b]{2}{*}{ Unit Usaha } & \multicolumn{3}{|c|}{2015} & \multicolumn{3}{|c|}{2016} \\
\hline & & $\begin{array}{l}\text { Luas } \\
\text { Areal } \\
\text { (ha) }\end{array}$ & $\begin{array}{l}\text { Produksi } \\
\quad(\mathrm{kg})\end{array}$ & $\begin{array}{c}\text { Produktivita } \\
\text { s } \\
(\mathrm{kg} / \mathrm{ha})\end{array}$ & $\begin{array}{c}\text { Luas } \\
\text { Areal } \\
\text { (ha) }\end{array}$ & $\begin{array}{l}\text { Produksi } \\
\quad(\mathrm{kg})\end{array}$ & $\begin{array}{c}\text { Produktivita } \\
\text { s } \\
(\mathrm{kg} / \mathrm{ha})\end{array}$ \\
\hline 1 & Ophir & $2.619,00$ & 59.092 .000 & 22.563 & $3.186,00$ & 72.731 .510 & 22.828 \\
\hline 2 & Bunut & $1.181,95$ & 21.936 .000 & 18.560 & $1.526,49$ & 23.858 .000 & 15.629 \\
\hline 3 & $\begin{array}{l}\text { Tanjung } \\
\text { Lebar }\end{array}$ & $1.832,50$ & 26.710 .000 & 14.576 & $1.001,40$ & 15.380 .000 & 15.358 \\
\hline 4 & Rimdu & $3.270,00$ & 87.255 .000 & 26.683 & $3.270,00$ & 71.220 .300 & 21.780 \\
\hline 5 & Rimsa & $3.476,70$ & 95.332 .000 & 27.420 & $3.476,70$ & 86.396 .000 & 24.850 \\
\hline 6 & $\begin{array}{l}\text { Batangha } \\
\text { ri }\end{array}$ & $\begin{array}{c}2.025,0 \\
0\end{array}$ & $\begin{array}{c}61.338 .00 \\
0\end{array}$ & 30.290 & $\begin{array}{c}2.025,0 \\
0\end{array}$ & $\begin{array}{c}61.844 .00 \\
0\end{array}$ & 30.540 \\
\hline 7 & $\begin{array}{l}\text { Durian } \\
\text { Luncuk }\end{array}$ & $4.476,00$ & 94.625 .000 & 21.140 & $4.476,00$ & 79.437 .000 & 17.747 \\
\hline 8 & $\begin{array}{l}\text { Solok } \\
\text { Selatan } \\
\text { Pangkalan }\end{array}$ & $3.567,00$ & 72.785 .000 & 20.405 & $3.567,00$ & 63.354 .000 & 17.761 \\
\hline 9 & $\begin{array}{l}\text { Lima } \\
\text { Puluh Kota }\end{array}$ & $1.366,00$ & 26.479 .000 & 19.384 & $1.366,00$ & 25.166 .000 & 18.423 \\
\hline 10 & $\begin{array}{l}\text { Bukit } \\
\text { Cermin }\end{array}$ & 538,90 & 6.210 .000 & 11.523 & 920,00 & 7.165 .842 & 7.789 \\
\hline
\end{tabular}

Sumber : Capaian Produksi PTPN VI tahun 2015 - 2016

Pada Tabel 1 dapat dilihat bahwa pada Tahun 2015 - 2016 Unit Usaha Batanghari tidak ada perubahan luas areal namun mengalami peningkatan jumlah produktivitas dan jika dilihat secara keseluruhan Unit Usaha yang ada ternyata Unit Usaha Batanghari mempunyai jumlah produktivitas yang paling tinggi.

Perusahaan selalu berusaha mendorong produktivitas tenaga kerja untuk mencapai target yang ditetapkan. Produktivitas kerja adalah kemampuan menghasilkan barang atau jasa dari suatu tenaga kerja manusia, mesin atau faktor produksi lainnya, dihitung berdasarkan waktu rata-rata dari tenaga tersebut dalam proses produksi (Sumarsono, 2009).

Tenaga kerja pemanen yang produktif dapat dilihat dari pencapaian target yang telah ditetapkan perusahaan atau selisih antara hasil yang diperoleh dengan basis tugas yang telah ditetapkan perusahaan. Jika produktivitas tenaga kerja pemanen baik, maka produksi perusahaan akan meningkat dan target perusahaan dapat tercapai. Sebaliknya, jika produktivitas tenaga kerja pemanen rendah, maka produksi akan menurun dan target perusahaan akan sulit tercapai, sehingga perusahaan akan berupaya mendorong produktivitas tenaga kerja yang dimilikinya. Sehingga penting untuk mengetahui apa saja faktorfaktor yang mempengaruhi produktivitas tenaga kerja panen kelapa sawit pada Unit Usaha Batanghari di PTPN VI Jambi.

\section{METODOLOGI PENELITIAN}

Ruang lingkup penelitian ini difokuskan pada tingkat produktivitas tenaga kerja panen kelapa sawit dan subyek yang diteliti adalah gambaran tentang kegiatan usahatani kelapa sawit pada Unit Usaha Batanghari di PTPN VI Jambi, gambaran produktivitas tenaga kerja panen kelapa sawit, faktor umur, lama pendidikan, masa kerja, jarak tempuh, jumlah tanggungan keluarga dan status tenaga kerja yang mempengaruhi produktivitas tenaga kerja panen kelapa sawit, serta pengaruh faktor-faktor tersebut terhadap produktivitas tenaga kerja panen kelapa sawit. 
Metode yang digunakan dalam penelitian ini adalah metode survey. Data yang dikumpulkan dalam penelitian ini bersumber dari data primer dan data sekunder. Data primer diperoleh dari responden melalui wawancara dengan menggunakan daftar quesioner yang telah disusun sesuai dengan tujuan penelitian dan berdasarkan pengamatan dilapangan. Sedangkan data sekunder diperoleh dari perusahaan yang berhubungan dengan kegiatan penelitian.

Pengambilan sampel pemanen kelapa sawit dengan menggunakan metode simple random sampling, yaitu pengambilan sampel sedemikian rupa sehingga tiap unit penelitian atau elemen yang terdiri dari populasi memiliki kesempatan yang sama untuk dipilih sebagai sampel. Menurut Winarno (1994), mengemukakan bahwa untuk pedoman umum saja dapat dikatakan bahwa bila populasi cukup homogen terhadap populasi dibawah 100 dapat dipergunakan sampel sebesar 50\%, dan apabila populasi diatas 100 dapat diambil sampel sebesar 15\%. Berdasarkan pendapat Winarno maka diambil sampel sebesar $15 \%$ dan sebaiknya untuk sampel manusia diatas 30, maka sampel yang diambil adalah 31 orang (24\%) dari total tenaga kerja panen (130).

Penelitian ini menggunakan metode deskriptif analitis yaitu metode dalam penelitian suatu kelompok manusia, suatu objek, suatu kondisi, suatu sistem, pemikiran ataupun suatu klasifikasi peristiwa pada masa sekarang (Nazir, 1983).

Selain metode deskriptif analitis yang dilaksanakan dengan studi kasus, penelitian ini juga menggunakan metode analisis statistik induktif yaitu suatu analisis data spesifik sehingga dapat memberikan hasil yang bersifat umum.

Untuk mengetahui tingkat produktivitas tenaga kerja panen di lokasi penelitian menurut Aroef (1985), produktivitas tenaga kerja adalah hasil produksi persatuan waktu yang dapat dirumuskan sebagai berikut :

Produktivitas Tenaga Kerja Panen

$=\frac{\text { Hasil Produksi }(\mathrm{kg})}{\text { Satuan Waktu (hari) }}$

Selanjutnya untuk menguji faktorfaktor yang mempengaruhi produktivitas tenaga kerja panen digunakan uji hipotesis (Husaini, 2008) dengan metode persamaan regresi linier berganda.

Dalam penelitian ini juga akan dilakukan uji Fhitung untuk mengetahui signifikan pengaruh variabel bebas (independen variabel $=\mathrm{X}_{\mathrm{i}}$ ) terhadap variabel terikat (dependen variabel $=\mathrm{Y}$ ) secara bersama-sama atau pengujian kesesuaian model. Pengujian ini digunakan untuk memperkirakan apakah variabel tidak bebas (dependen variabel $=$ Y) bekolerasi $/$ berhubungan secara linier terhadap variabel (independen variabel $=\mathrm{X}_{\mathrm{i}}$ ) secara bersama-sama (Sudjana, 1992).

Pengujian terhadap masing-masing parameter ditujukan untuk mengetahui apakah masing-masing variabel bebas (independen variabel $=\mathrm{X}_{\mathrm{i}}$ ) secara individu berpengaruh terhadap variabel tidak bebas (dependen variabel $=\mathrm{Y}$ ) (Sudjana, 1992). Pengujiannya dilakukan dengan menggunakan uji thitung sebagai berikut :

thitung $=\frac{b_{i}}{S\left(b_{i}\right)}$

Dimana :

$b_{i} \quad$ : koefisien regresi

$S\left(b_{i}\right)$ : standar deviasi

$\mathrm{n} \quad$ : jumlah sampel

k : konstanta

Hipotesis statistik yang diuji :

$\mathrm{H}_{0}: \mathrm{b}_{\mathrm{i}}=0$. terima $\mathrm{H}_{0}$, artinya bahwa tidak ada pengaruh antara variabel bebas $(\mathrm{X})$ terhadap variabel terikat $(\mathrm{Y})$. $\mathrm{H}_{\mathrm{a}}: \mathrm{b}_{\mathrm{i}} \neq 0$. tolak $\mathrm{H}_{\mathrm{a}}$, artinya bahwa terdapat pengaruh antara variabel bebas $(\mathrm{X})$ terhadap variabel terikat $(\mathrm{Y})$.

Kriteria pengujiannya adalah :

$\mathrm{H}_{0}$ diterima jika thitung $\leq t_{\text {tabel }}$ berarti tidak ada pengaruh antara variabel 
bebas (independen variabel $=\mathrm{X}$ ) terhadap variabel tidak bebas (dependen variabel $=\mathrm{Y}$ ).

$\mathrm{H}_{\mathrm{a}}$ ditolak jika thitung $>\mathrm{t}_{\text {tabel }}$ berarti ada pengaruh antara variabel bebas (independen variabel $=\mathrm{X}$ ) terhadap variabel tidak bebas (dependen variabel $=$ Y).

Beberapa konsepsi dan pengukuran variabel dalam penelitian ini adalah sebagai berikut :

1. Gambaran kegiatan perusahaan adalah kegiatan untuk kelapa sawit dari aspek hulu, produksi dan hilir

2. Responden adalah tenaga kerja panen kelapa sawit yang bekerja di PTPN VI Unit Usaha Batanghari Kabupaten Muaro Jambi.

3. Produktivitas tenaga kerja panen pada perkebunan kelapa sawit adalah kemampuan pemanen untuk menghasilkan jumlah Tandan Buah Segar (TBS) yang dapat diperoleh pemanen setiap harinya (kg/hari).

4. Umur adalah usia responden saat penelitian dilakukan (tahun).

5. Lama pendidikan adalah lama waktu yang ditempuh untuk menyelesaikan pendidikan formal (tahun).

6. Masa kerja adalah jangka waktu responden bekerja di perkebunan, sejak mulai bekerja sampai saat penelitian (tahun).

7. Jarak tempuh adalah jarak antara tempat tinggal responden dengan tempat kerja $(\mathrm{km})$.

8. Jumlah tanggungan keluarga adalah jumlah anggota keluarga yang masih dalam tanggungan kepala keluarga (orang).

9. Status tenaga kerja adalah jenis golongan antara responden dengan ketentuan nilai dummy sebagai berikut:

D ; 1 untuk karyawan tetap ; 0 untuk karyawan lepas

10. Hasil produksi adalah jumlah sawit yang berhasil dikumpulkan oleh responden $(\mathrm{kg})$.
HASIL DAN PEMBAHASAN

Identitas Tenaga Kerja Panen Kelapa Sawit

Identifikasi tenaga kerja panen kelapa sawit merupakan latar belakang dari pemanen. Dengan mengetahui keadaan pemanen kelapa sawit, kita dapat mengetahui perbedaan masingmasing seperti umur, lama pendidikan, masa kerja, jarak tempuh, jumlah tanggungan keluarga dan status tenaga kerja.

Umur pemanen kelapa sawit mempengaruhi kemampuan fisik dalam memanen Tandan Buah Segar (TBS) kelapa sawit. Semakin tinggi umur pemanen akan semakin rendah pula kemampuannya untuk bekerja dalam menghasilkan TBS.

Lama pendidikan akan berpengaruh terhadap cara berpikir dalam pengambilan keputusan serta perilaku pemanen kelapa sawit. Pemanen kelapa sawit yang menempuh pendidikan tinggi maka cara berpikirnya akan lebih maju, dengan demikian perbuatannya akan semakin baik dan secara sadar akan memenuhi keinginan dan kebutuhannya.

Masa kerja mencerminkan pengalaman yang dimiliki pemanen dalam memanen TBS. Pemanen yang sudah lama bekerja lebih mampu untuk mengenal seluk beluk permasalahan yang dihadapi, sehingga lebih mampu untuk mengatasinya. Pekerjaan yang sudah berulang-ulang dilakukan dalam jangka panjang akan membuat seseorang lebih cekatan dan terampil dalam melaksanakan tugasnya.

Jarak tempuh akan berpengaruh terhadap waktu dan tenaga yang dibutuhkan oleh tenaga kerja panen untuk sampai di tempat kerja. Semakin jauh jarak yang ditempuh maka akan mengurangi tenaga pemanen.

Jumlah tanggungan keluarga akan mempengaruhi pemanen sehingga dapat mendorong dan memotivasi tenaga kerja panen untuk meningkatkan produktivitasnya. 
Semakin banyak keluarga yang ditanggung maka akan menambah produktivitas pemanen.

Status tenaga kerja akan mempengaruhi tenaga kerja lewat pemberian gaji akan dipengaruhi oleh produktivitasnya. Apabila tingkat penghasilan memadai, maka dapat menimbulkan konsentrasi kerja, dan kemampuan yang dimiliki dapat dimanfaatkan untuk meningkatkan produktivitas

\section{Kegiatan Usaha Tani Kelapa Sawit Pada Unit Usaha Batanghari}

Pada Unit Usaha Batanghari di PTPN VI Jambi kegiatan usaha tani kelapa sawit sudah dilakukan sejak tahun 1999 atau sejak perusahaan mengganti komoditas karet menjadi komoditas kelapa sawit. Penggunaan bibit tanaman kelapa sawit di daerah penelitian menggunakan bibit jenis Tenera yang didapatkan dari Marihat dan PT. Sopindo. Dan untuk mempermudah proses pemanenan, peralatan yang digunakan oleh tenaga kerja panen yaitu dodos, egrek, kampak, gancu, beko, helm, sarung tangan, sepatu boot dan karung untuk tempat brondolan.

Keadaan tanaman kelapa sawit di daerah penelitian rata-rata berumur 18 dan 13 tahun dengan jarak tanam 9,1 meter Utara-Selatan dan 7,7 meter Timur-Barat dengan jumlah 143 pokok perhektar.

Sedangkan untuk pemupukan dan penanggulangan hama penyakit, perusahaan menggunakan obat-obatan kimia untuk mengatasi penyakit dan hama pada kelapa sawit seperti gliposat dan parakuat yang digunakan secara spontan serta glisat, rondap, dan erekrot yang digunakan secara perlahan (sistematis/ bertahap). Pupuk yang digunakan adalah NPK dan dolomite.

Sistem pemanenan diperusahaan memiliki kategori salah satunya adalah brondolan yang jatuh sekitar 15 biji maka wajib untuk dipanen. Frekuensi panen untuk satu batangnya sebanyak 3 kali dalam 1 bulan dan untuk setiap tenaga kerja panen memiliki tanggung jawab untuk memanen luasan areal kelapa sawit setiap hari sebanyak $2 \mathrm{Ha}$. Di waktu pemanenan terdapat mandor pemanen yang bertanggung jawab untuk mengawasi proses pemanenan dengan luasan areal $40 \mathrm{Ha}$ /hari. Setelah dipanen, tenaga kerja panen melapor kepada mandor panen untuk dicatat jumlah produktivitasnya dalam satu hari. Setelah itu, mandor panen akan melapor kepada Krani Catat Sawit (KCS) kemudian diberikan kepada Krani produksi untuk disimpan sebagai acuan untuk upah tenaga kerja panen. Setelah itu hasil panen tersebut diangkut ke truk dan kemudian langsung diantar ke Pabrik Kelapa Sawit Bunut.

\section{Produktivitas Tenaga Kerja Panen Kelapa Sawit}

Produktivitas tenaga kerja panen kelapa sawit menunjukkan jumlah TBS yang dihasilkan pemanen untuk setiap satuan waktu tertentu. Hasil standar jumlah TBS yang ditetapkan oleh PTPN VI Jambi adalah $950 \mathrm{~kg}$ TBS/hari, tapi untuk Perjanjian Kerja Waktu Tertentu (PKWT) tidak ditetapkan jumlah TBS yang harus dipanen dalam satu hari kerja.

Tabel 2. Distribusi Dan Frekuensi Produktivitas Tenaga Kerja Panen

\begin{tabular}{cccc}
\hline N & $\begin{array}{c}\text { Produktivita } \\
\text { s Tenaga } \\
\text { Kerja Panen } \\
\text { (kg/hari) }\end{array}$ & $\begin{array}{c}\text { Frekuens } \\
\text { i (orang) }\end{array}$ & $\begin{array}{c}\text { Persentas } \\
\text { e } \\
(\%)\end{array}$ \\
\hline 1 & $760-966$ & 2 & 6.45 \\
2 & $967-1173$ & 6 & 19.35 \\
3 & $1174-1380$ & 5 & 16.13 \\
4 & $1381-1587$ & 8 & 25.81 \\
5 & $1588-1794$ & 2 & 6.45 \\
6 & $1795-2001$ & 8 & 25.81 \\
\hline & Jumlah & 31 & 100.00 \\
\hline
\end{tabular}

Berdasarkan Tabel 3 diatas dapat dilihat bahwa produktivitas tenaga kerja panen tertinggi antara 1381 $1587 \mathrm{~kg} /$ hari sebesar 25,81\% atau sebanyak 8 orang dan tenaga kerja panen terendah antara 760 - 966 
$\mathrm{kg} /$ hari sebesar 6,45\% atau sebanyak 2 orang.

\section{Gambaran Faktor-Fakor Yang Mempengaruhi Produktivitas Tenaga Kerja Panen Kelapa Sawit}

1. Umur Tenaga Kerja Panen

Tenaga kerja panen sangat mengandalkan tenaga dan keadaan fisiknya dalam melaksanakan pekerjaannya, maka faktor umur sangat berpengaruh terhadap produktivitas tenaga kerja panen kelapa sawit.

Tabel 3. Distribusi Dan Frekuensi Umur Tenaga Kerja Panen

\begin{tabular}{cccc}
\hline No & $\begin{array}{c}\text { Umur } \\
\text { Tenaga } \\
\text { Kerja } \\
\text { Panen } \\
\text { (tahun) }\end{array}$ & $\begin{array}{c}\text { Frekuensi } \\
\text { (orang) }\end{array}$ & $\begin{array}{c}\text { Persentase } \\
(\%)\end{array}$ \\
\hline 1 & $20-25$ & 1 & 3,23 \\
2 & $26-31$ & 2 & 6,45 \\
3 & $32-37$ & 9 & 29,03 \\
4 & $38-43$ & 7 & 22,58 \\
5 & $44-49$ & 8 & 25,81 \\
6 & $50-55$ & 4 & 12,90 \\
\hline & Jumlah & 31 & 100.00 \\
\hline
\end{tabular}

Sumber : Data Tenaga Kerja Panen Unit Usaha Batanghari

Berdasarkan Tabel 4 diatas bahwa umur tenaga kerja panen yang tertinggi yaitu 32 - 37 tahun sebesar 29,03\% atau sebanyak 9 orang dan umur tenaga kerja panen yang terendah antara 20 25 tahun sebesar 3,23\% atau sebanyak 1 orang.

Umur tersebut termasuk dalam umur produktif (17-55 tahun) baik dalam arti fisik maupun biologis, sehingga mendukung dalam upaya meningkatkan produktivitas tenaga kerja panen kelapa sawit. Semakin bertambahnya umur tenaga kerja panen kelapa sawit maka kemampuan fisiknya semakin menurun dan curahan tenaga kerja yang diberikan semakin berkurang sehingga produktivitasnya akan menurun.

2. Lama Pendidikan

Lamanya pendidikan yang ditempuh oleh tenaga kerja panen akan berpengaruh terhadap cara berpikir dalam pengambilan keputusan serta perilaku pemanen kelapa sawit. Pemanen kelapa sawit yang menempuh pendidikan tinggi maka cara berpikirnya akan lebih maju.

Tabel 4. Distribusi Dan Frekuensi Lama Pendidikan Tenaga Kerja Panen

\begin{tabular}{cccc}
\hline No & $\begin{array}{c}\text { Lama } \\
\text { Pendidikan } \\
\text { (tahun) }\end{array}$ & $\begin{array}{c}\text { Frekuensi } \\
\text { (orang) }\end{array}$ & $\begin{array}{c}\text { Persentase } \\
(\%)\end{array}$ \\
\hline 1 & $6-7,5$ & 8 & 25,80 \\
2 & $7,5-8,9$ & 0 & 0 \\
3 & $9-10,4$ & 14 & 45,16 \\
4 & $10,5-11,9$ & 0 & 0 \\
5 & $12-13,4$ & 9 & $0,29,03$ \\
6 & $13,5-14,9$ & 0 & 0 \\
\hline & Jumlah & 31 & 100.00 \\
\hline
\end{tabular}

Berdasarkan Tabel 5 diatas dapat dilihat bahwa lama pendidikan tenaga kerja panen yang tertinggi antara 9 10,4 tahun sebesar $45,16 \%$ atau sebanyak 14 orang dan lama pendidikan tenaga kerja panen yang terendah antara $6-7,4$ tahun sebesar $25,80 \%$ atau sebanyak 8 orang. Perusahaan tidak menetapkan tingkat pendidikan untuk menjadi tenaga kerja panen.

Pendidikan yang dimaksud dalam penelitian ini adalah pendidikan formal yang dimiliki tenaga kerja panen. Distribusi frekuensi tenaga kerja panen berdasarkan tingkat pendidikan dapat dilihat pada Tabel 6.

Tabel 5. Ditribusi Dan Frekuensi Tingkat Pendidikan Tenaga Kerja Panen

\begin{tabular}{cccc}
\hline No & $\begin{array}{c}\text { Tingkat } \\
\text { Pendidikan }\end{array}$ & $\begin{array}{c}\text { Frekuensi } \\
\text { (orang) }\end{array}$ & $\begin{array}{c}\text { Persentase } \\
(\%)\end{array}$ \\
\hline 1 & SD & 8 & 25,80 \\
2 & SMP & 14 & 45,16 \\
3 & SMA & 9 & 29,03 \\
\hline & Jumlah & 31 & 100.00 \\
\hline
\end{tabular}

Berdasarkan Tabel 6 diatas dapat dilihat bahwa tingkat pendidikan tenaga kerja panen yang tertinggi adalah Sekolah Menengah Pertama (SMP) sebesar 45,16\% atau sebanyak 14 orang dan tingkat pendidikan tenaga kerja panen yang terendah adalah Sekolah Dasar (SD) sebesar 25,81\% atau sebanyak 8 orang. Perusahaan 
tidak menetapkan tingkat pendidikan untuk menjadi tenaga kerja panen.

\section{Masa Kerja}

Dari hasil penelitian, masa kerja tenaga kerja panen berkisar antara 1 15 tahun. Komposisi masa kerja tenaga kerja panen dapat dilihat pada Tabel 7. Tabel 6. Distribusi Dan Frekuensi Masa Kerja Tenaga Kerja Panen

\begin{tabular}{cccc}
\hline No & $\begin{array}{c}\text { Masa Kerja } \\
\text { (tahun) }\end{array}$ & $\begin{array}{c}\text { Frekuensi } \\
\text { (orang) }\end{array}$ & $\begin{array}{c}\text { Persentase } \\
(\%)\end{array}$ \\
\hline 1 & $1-3,4$ & 1 & 3,23 \\
2 & $3,5-5,9$ & 4 & 12,90 \\
3 & $6-8,4$ & 4 & 12,90 \\
4 & $8,5-10,5$ & 14 & 45,16 \\
5 & $11-13,4$ & 2 & 6,45 \\
6 & $13,5-15,9$ & 6 & 19,35 \\
\hline & Jumlah & 31 & 100.00 \\
\hline
\end{tabular}

Berdasarkan Tabel 7 diatas dapat dilihat bahwa masa kerja tenaga kerja panen yang tertinggi adalah 8,5 - 10,5 tahun sebesar $45,16 \%$ atau sebanyak 14 orang dan masa kerja tenaga kerja panen yang terendah adalah $1-3,4$ tahun sebesar 3,23\% atau sebanyak 1 orang. Dengan demikian semakin lama masa kerja tenaga kerja panen maka diharapkan produktivitas tenaga kerja panen dapat meningkat.

4. Jarak Tempuh

Dari hasil penelitian, jarak yang ditempuh pemanen kelapa sawit dari rumah ke tempat kerja berkisar antara 2 - $7 \mathrm{~km}$. untuk lebih jelasnya dapat dilihat pada Tabel 8.

Tabel 7. Distribusi Dan Frekuensi Jarak Tempuh Tenaga Kerja Panen

\begin{tabular}{cccc}
\hline No & $\begin{array}{c}\text { Jarak } \\
\text { Tempuh } \\
(\mathrm{km})\end{array}$ & $\begin{array}{c}\text { Frekuensi } \\
\text { (orang) }\end{array}$ & $\begin{array}{c}\text { Persentase } \\
(\%)\end{array}$ \\
\hline 1 & 2 & 3 & 9,6 \\
2 & 3 & 16 & 51,61 \\
3 & 4 & 6 & 19,35 \\
4 & 5 & 5 & 16,13 \\
5 & 6 & 0 & 0 \\
6 & 7 & 1 & 3,23 \\
\hline & Jumlah & 31 & 100.00 \\
\hline
\end{tabular}

Sumber : Data Tenaga Kerja Panen Unit Usaha Batanghari

Berdasarkan Tabel 8 diatas dapat dilihat bahwa jarak tempuh tenaga kerja panen tertinggi adalah sejauh 3 $\mathrm{km}$ sebesar 51,61\% atau sebanyak 16 orang dan jarak tempuh tenaga kerja panen yang terendah sejauh $7 \mathrm{~km}$ sebesar 3,23\% atau sebanyak 1 orang. Secara umum rata-rata jarak yang ditempuh tenaga kerja panen ke lokasi kerja sekitar $3 \mathrm{~km}$, artinya jarak tempuh yang tidak terlalu jauh ini tidak mempengaruhi stamina dan semangat tenaga kerja panen untuk bekerja. Sehingga diharapkan produktivitas tenaga kerja panen tinggi.

5. Jumlah Tanggungan Keluarga

Tenaga kerja panen dengan jumlah anggota keluarga kurang dari 3 orang digolongkan sebagai tanggungan sedikit. Sedangkan lebih dari 5 orang digolongkan banyak dan tanggungan keluarga 3 - 4 orang termasuk sedang. Perusahaan menanggung paling banyak 3 orang anak atau disebut K3 yaitu keluarga dengan 3 orang anak. Jumlah tanggungan keluarga tenaga kerja panen dapat dilihat pada Tabel 9.

Tabel 8. Distribusi Dan Frekuensi Jumlah Tanggungan Keluarga Tenaga Kerja Panen

\begin{tabular}{cccc}
\hline $\mathrm{N}$ & $\begin{array}{c}\text { Jumlah } \\
\text { Tanggunga } \\
\text { n Keluarga } \\
\text { (orang) }\end{array}$ & $\begin{array}{c}\text { Frekuens } \\
\text { i (orang) }\end{array}$ & $\begin{array}{c}\text { Persentas } \\
\mathrm{e} \\
(\%)\end{array}$ \\
\hline 1 & 0 & 4 & 12,90 \\
2 & 1 & 2 & 6,45 \\
3 & 2 & 9 & 29,03 \\
4 & 3 & 8 & 25,81 \\
5 & 4 & 8 & 25,81 \\
6 & 5 & 0 & 0 \\
\hline & Jumlah & 31 & 100.00 \\
\hline
\end{tabular}

Berdasarkan Tabel 9 diatas dapat dilihat bahwa jumlah tanggungan keluarga tenaga kerja panen tertinggi sebesar 29,03\% atau sebanyak 9 orang dengan jumlah tanggungan keluarga sebanyak 2 orang dan jumlah tanggungan keluarga tenaga kerja panen terendah adalah 6,45\% atau sebanyak 2 orang dengan jumlah tanggungan keluarga sebanyak 1 orang.

6. Status Tenaga Kerja

Dari hasil penelitian, status tenaga kerja didaerah penelitian terbagi menjadi karyawan tetap dan karyawan 
lepas. Karyawan tetap mempunyai tanggung jawab untuk memanen TBS sesuai dengan ketetapan perusahaan, sedangkan karyawan lepas tidak mempunyai tanggung jawab untuk memanen TBS sesuai dengan ketetapan perusahaan. Untuk lebih jelasnya dapat dilihat pada Tabel 10.

Tabel 9. Distribusi Dan Frekuensi Status Tenaga Kerja Panen

\begin{tabular}{cccc}
\hline \multirow{2}{*}{ No } & \multirow{2}{*}{ Status } & \multicolumn{2}{c}{ Nilai } \\
& Tenaga Kerja & \multicolumn{2}{c}{ Dummy } \\
\cline { 3 - 4 } & Karyawan & $(1)$ & $(0)$ \\
\hline 1 & Tetap & 4 & - \\
2 & Karyawan & - & 27 \\
& Lepas & & \\
\hline
\end{tabular}

Sumber : Data Tenaga Kerja Panen Unit Usaha Batanghari

Berdasarkan Tabel 10 diatas dapat dilihat bahwa identitas tenaga kerja panen yang merupakan karyawan tetap sebanyak 4 orang dan yang merupakan karyawan lepas sebanyak 27 orang.
Pengaruh Faktor-Faktor Terhadap Produktivitas Tenaga Kerja Panen Pengaruh Secara Simultan

Produktivitas tenaga kerja panen yang bekerja di perkebunan kelapa sawit pada Unit Usaha Batanghari di PTPN VI Jambi cukup tinggi, yaitu sebesar 1.435 $\mathrm{kg} /$ orang/hari.

Hipotesis menyatakan bahwa diduga faktor umur, lama pendidikan, masa kerja, jarak tempuh, jumlah tanggungan keluarga, dan status tenaga kerja mempengaruhi produktivitas tenaga kerja panen kelapa sawit pada Unit Usaha Batanghari di PTPN VI Jambi.

Berdasarkan hasil analisis regresi linier berganda dengan bantuan program SPSS diperoleh hasil seperti pada Tabel 11.

Tabel 10. Hasil Analisis Faktor-Faktor yang Mempengaruhi Produktivitas Tenaga Kerja Panen

\begin{tabular}{lclcrc}
\hline No & Nama Variabel & Keterangan & KoefisienRegresi & thitung & Sig \\
\hline 1 & X1 & Umur & -0.034 & -0.002 & 0.998 \\
2 & X2 & Lama Pendidikan & 2.878 & 0.098 & 0.923 \\
3 & X3 & Masa Kerja & 55.780 & 1.902 & 0.069 \\
4 & X4 & Jarak Tempuh & 9.471 & 0.156 & 0.877 \\
5 & X5 & Jumlah Tanggungan & & & \\
& Deluarga & 27.189 & 0.439 & 0.665 \\
6 & Status Tenaga Kerja & -695.260 & -2.817 & 0.010 \\
& & Konstanta & 853.417 & 1.513 & 0.143 \\
\hline
\end{tabular}

$\begin{array}{ll}\mathrm{R}^{2} & =0.150 \\ \text { Fhitung } & =1.882 \\ F_{\text {tabel }} & =2.508 \\ \text { tabel } & =2.064\end{array}$

Berdasarkan Tabel 11 bahwa tingkat produktivitas tenaga kerja panen kelapa sawit dipengaruhi oleh faktor umur, lama pendidikan, masa kerja, jarak tempuh, jumlah tanggungan keluarga dan status tenaga kerja.

Persamaan yang terbentuk dari hasil analisis regresi linier berganda adalah sebagai berikut :

$$
\begin{aligned}
\mathrm{Y}= & 853.417-0.034 \mathrm{X} 1+2.878 \mathrm{X} 2+ \\
& 55.780 \mathrm{X} 3+9.471 \mathrm{X} 4+27.189 \mathrm{X} 5 \\
& -695.260 \mathrm{D}+\mathrm{e}
\end{aligned}
$$

Dari hasil analisis regresi linier berganda dengan menggunakan data tenaga kerja di daerah penelitian diperoleh nilai adjusted $\mathrm{R}^{2}$ sebesar 0.150 atau (15\%). Hasil perhitungan Fhitung sebesar 1.882 dan Ftabel 2.508 dengan demikian $F_{\text {hitung }} \leq \mathrm{F}_{\text {tabel }}$ terima $\mathrm{H}_{0}$ berarti tidak ada pengaruh secara simultan antara variabel bebas (independen variabel $=\mathrm{X}$ ) terhadap variabel terikat (dependen variabel $=\mathrm{Y}$ ) yang artinya faktor tersebut hanya 
mempengaruhi sebesar $15 \%$ dan sisanya sebesar $85 \%$ dipengaruhi oleh faktor lain yang tidak termasuk dalam perhitungan.

\section{Pengaruh Parsial}

Untuk melihat apakah variabel independent dapat mempengaruhi variabel dependent secara parsial terhadap produktivitas tenaga kerja panen, untuk itu digunakan uji $\mathrm{t}$.

Apabila $\left|t_{\text {thitung }}\right| \geq$ ttabel, artinya apabila variabel bebas (independen variabel = $\mathrm{X}$ ) secara individu berpengaruh nyata terhadap variabel terikat (dependen variabel $=$ Y). Sebaliknya bila $-t_{\text {tabel }}<$ thitung < tabel artinya apabila variabel bebas (independen variabel $=\mathrm{X}$ ) secara individu tidak berpengaruh nyata terhadap variabel terikat (dependen variabel $=$ Y).

Berdasarkan Tabel 10 dapat diketahui bahwa besarnya masingmasing thitung dan besarnya tabel, maka dapat dijelaskan pengaruh masingmasing faktor.

Untuk variabel X1 (umur), thitung $0.002 \leq$ tabel 2.064 artinya faktor umur tenaga kerja panen tidak berpengaruh nyata. Artinya, tenaga kerja panen golongan muda dan tua tidak terlalu berpengaruh terhadap produktivitas. Kegiatan memanen kelapa sawit merupakan pekerjaan yang mengutamakan kesehatan fisik dari tenaga kerja, jika kesehatan tenaga kerja menurun maka tenaga kerja tidak dapat memanen dengan baik dan produktivitas akan menurun.

Untuk variabel X2 (lama pendidikan), thitung $0.098 \leq t_{\text {tabel }} 2.064$ artinya faktor lama pendidikan tidak berpengaruh nyata terhadap produktivitas tenaga kerja panen. Artinya, perbedaan lama pendidikan tidak dapat menentukan naik atau turunnya produktivitasnya. Hal ini menunjukkan bahwa untuk pekerja lapang seperti tenaga kerja panen, produktivitas tidak dipengaruhi oleh pendidikan yang telah diselesaikan.
Untuk variabel X3 (masa kerja), thitung1.902 $\leq$ ttabel 2.064 artinya faktor masa kerja tenaga kerja panen tidak berpengaruh nyata terhadap produktivitas tenaga kerja panen. Artinya, pengalaman dan lamanya tenaga kerja panen bekerja tidak terlalu mempengaruhi naik turunnya produktivitas. Hal ini menunjukkan bahwa pengalaman kerja tenaga kerja panen tidak dipengaruhi masa kerja walaupun sudah terampil dan teliti dalam melaksanakan pekerjaannya.

Untuk variabel X4 (jarak tempuh), thitung $0.156 \leq t_{\text {tabel }} 2.064$ artinya faktor jarak tempuh tenaga kerja panen tidak berpengaruh nyata. Artinya, jauh dekatnya rumah tenaga kerja panen tidak terlalu mempengaruhi naik turunnya produktivtas. Hal ini menunjukkan bahwa jarak yang ditempuh tenaga kerja panen tidak mengurangi tenaga yang dibutuhkan tenaga kerja untuk memanen kelapa sawit.

Untuk variabel X5 (jumlah tanggungan keluarga), thitung $0.439 \leq$ ttabel 2.064 artinya faktor jumlah tanggungan keluarga tenaga kerja panen tidak berpengaruh nyata. Artinya, banyaknya anggota keluarga dari tenaga kerja panen tidak terlalu mempengaruhi produktivitas. Hal ini menunjukkan jumlah tanggungan keluarga tidak berdampak untuk mendorong pekerja dalam meningkatkan produktivitas kerjanya guna memperoleh pendapatan yang lebih tinggi

Untuk variabel D (status tenaga kerja), koefisien regresi sebesar 695.260, yang artinya bahwa produktivitas karyawan tetap lebih rendah sebesar $695.260 \%$ dari produktivitas karyawan lepas. Status tenaga kerja akan mempengaruhi tenaga kerja melalui pemberian gaji yang akan dipengaruhi oleh produktivitasnya. Artinya, bahwa gaji karyawan tetap sudah intens dan tidak dipengaruhi oleh produktivitasnya, 
berbeda dengan gaji karyawan lepas yang dipengaruhi oleh produktivitasnya. Dengan persamaan : $\mathrm{Y}=853.417-0.034 \mathrm{X} 1+2.878 \mathrm{X} 2+$ $55.780 \mathrm{X} 3+9.471 \mathrm{X} 427.189 \mathrm{X} 5-$ $695.260 \mathrm{D}+\mathrm{e}$

Ada perlakuan persamaan untuk dummy pada variabel identitas tenaga kerja :

a. Persamaan produktivitas karyawan tetap $(\mathrm{D}=1)$ adalah sebagai berikut

$$
\begin{array}{rl}
\mathrm{Y}= & 853.417-0.034 \mathrm{X} 1+2.878 \mathrm{X} 2+ \\
& 55.780 \mathrm{X} 3+9.471 \mathrm{X} 4+27.189 \\
& \mathrm{X} 5-695.260 \mathrm{D}+\mathrm{e} \\
\mathrm{Y} & 853.417-0.034 \mathrm{X} 1+2.878 \mathrm{X} 2+ \\
& 55.780 \mathrm{X} 3+9.471 \mathrm{X} 427.189 \mathrm{X} 5 \\
& -695.260(1)+\mathrm{e} \\
\mathrm{Y} & 1548.677-0.034 \mathrm{X} 1+2.878 \mathrm{X} 2 \\
& +55.780 \mathrm{X} 3+9.471 \mathrm{X} 4+ \\
& 27.189 \mathrm{X} 5+\mathrm{e}
\end{array}
$$

b. Persamaan produktivitas karyawan lepas $(\mathrm{D}=0)$ adalah sebagai berikut $\mathrm{Y}=853.417-0.034 \mathrm{X} 1+2.878 \mathrm{X} 2+$ $55.780 \mathrm{X3}+9.471 \times 427.189 \mathrm{X} 5$ $-695.260 \mathrm{D}+\mathrm{e}$

$\mathrm{Y}=853.417-0.034 \mathrm{X} 1+2.878 \mathrm{X} 2+$ $55.780 \mathrm{X} 3+9.471 \mathrm{X} 427.189 \mathrm{X} 5$ $-695.260(0)+\mathrm{e}$

$\mathrm{Y}=853.417+0.034 \mathrm{X} 1+2.878 \mathrm{X} 2+$ $55.780 \mathrm{X} 3+9.471 \mathrm{X} 4+27.189$ $\mathrm{X} 5+\mathrm{e}$

\section{SIMPULAN}

Kegiatan usahatani pada Unit Usaha Batanghari sudah tertata sedemikian rupa yang diatur oleh perusahaan. Keadaan tanaman kelapa sawit di daerah penelitian rata-rata berumur 18 dan 13 tahun dengan jarak tanam 9,1 meter Utara-Selatan dan 7,7 meter Timur-Barat dengan jumlah 143 pokok perhektar. Pemupukan dan penaggulangan hama penyakit, perusahaan menggunakan obat-obatan kimia untuk mengatasi penyakit dan hama pada kelapa sawit seperti gliposat dan parakuat yang digunakan secara spontan serta glisat, rondap, dan erekrot yang digunakan secara perlahan (sistematis/bertahap). Pupuk yang digunakan adalah NPK dan dolomite. Sistem pemanenan diperusahaan memiliki kategori salah satunya adalah brondolan yang jatuh sekitar 15 biji maka wajib untuk dipanen. Untuk setiap tenaga kerja panen memiliki tanggung jawab untuk memanen luasan areal kelapa sawit setiap hari sebanyak $2 \mathrm{Ha}$. Di waktu pemanenan terdapat mandor pemanen yang bertanggung jawab untuk mengawasi proses pemanenan dengan luasan areal $40 \mathrm{Ha} /$ hari. Setelah itu hasil panen tersebut kemudian langsung diantar ke Pabrik Kelapa Sawit Bunut. Rata-rata produktivitas tenaga kerja panen kelapa sawit pada Unit Usaha Batanghari di PTPN VI Jambi Secara simultan produktivitas tenaga kerja panen kelapa sawit tidak dipengaruhi oleh faktor umur, lama pendidikan, masa kerja, jarak tempuh, jumlah tanggungan keluarga dan status tenaga kerja sebesar $15 \%$ dan sisanya 85\% dipengaruhi oleh faktor-faktor lain yang tidak diperhitungkan dalam penelitian ini. Faktor-faktor yang mempengaruhi produktivitas tenaga kerja panen kelapa sawit secara parsial dipengaruhi oleh status tenaga kerja (D), sedangkan faktor yang tidak berpengaruh nyata adalah umur (X1), lama pendidikan (X2), masa kerja (X3), jarak tempuh (X4), jumlah tanggungan keluarga (X5).

\section{DAFTAR PUSTAKA}

Aroef, M dan Joel, E.R. 1985. Produktivitas dan Teknologi. Kumpulan Kertas Kerja, STTUP. Jakarta.

Fauzi,Yan. 2012. Kelapa Sawit. Budi Daya, Pemanfaatan Hasil dan Limbah, Analisis Usaha dan Pemasaran. Jakarta. Penebar Swadaya.

Nazir, M. 1983. Metode Penelitian. Ghalia Indonesia. Jakarta. 
Soekartawi. 1987. Prinsip Dasar Ekonomi Pertanian Teori Dan Aplikasi. Rajawali Pers. Jakarta.

Sudjana. 1992. Metode Statistika. Bandung.

Sumarsono, S. 2009. Teori dan Kebijakan Publik Ekonomi
Sumber Daya Manusia. Graha Ilmu. Yogyakarta.

Winarno. S. 1994. Pengantar Peneltian Ilmiah (dalam metode teknik). Kanasius. Bandung. 